水》ノ

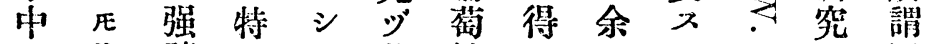

二些 硫 二 三截糖公ル四少反

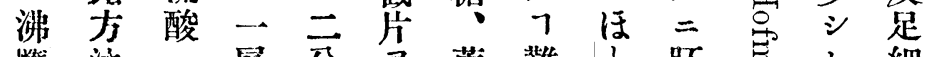

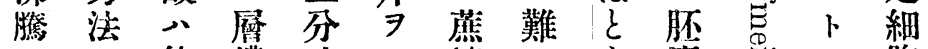

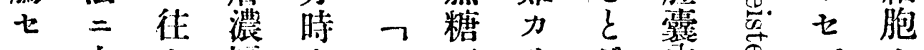

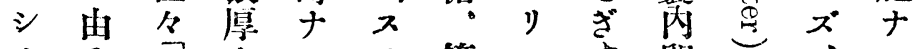

メ テ グナラ ラ 等 シ

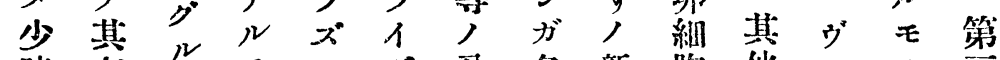

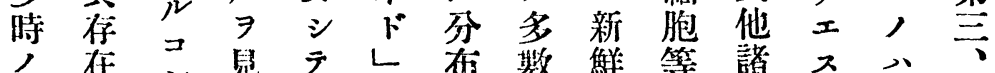

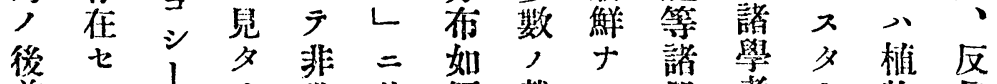

前ルドリ常載何截ル器者1物超

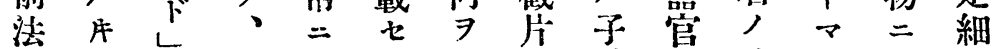

二卜 澱之美 $\leadsto$ 知 $\Rightarrow$ 磨或論々 由胞

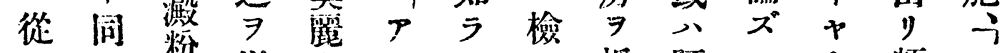

テ - 粉以

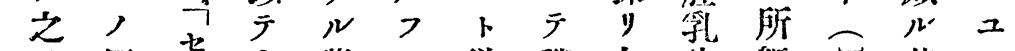

㕅七上紫

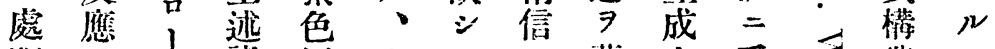

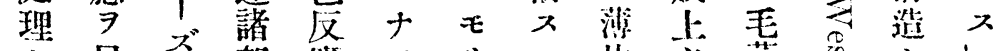

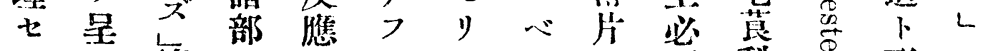

シ $入$ 等

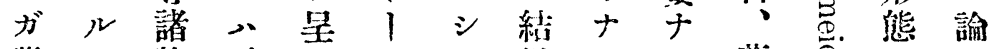

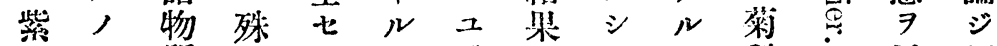

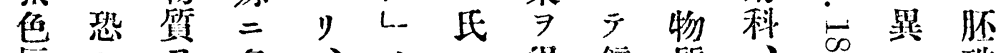

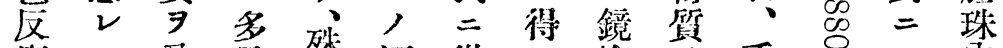

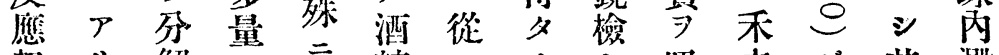

起り解, 三精七少七吸本ウ”其潵

ル、シ 溶二浴子余

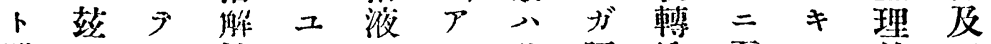

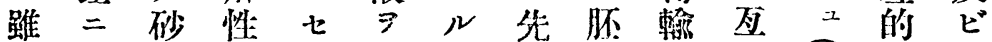

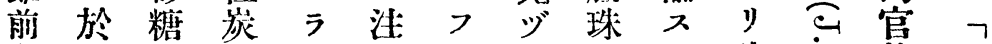

者 $\ni$ 水

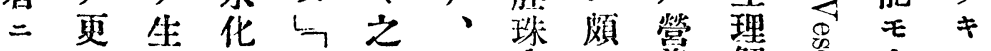

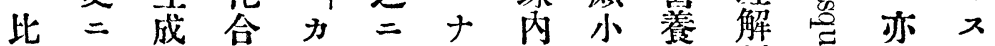

シ $\Omega$ 物 ラ强 フ二形器剖导頗 1

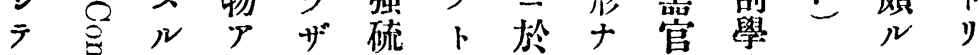

著总无

陌

クトナ知ビ三十浴满ト官ヤル體

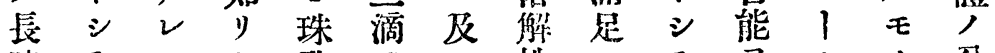

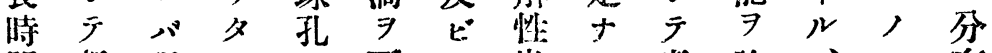

間啋現りノ下子管心考論、ア布

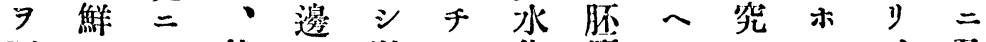

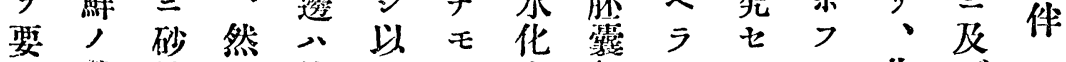

シ 截糖レ他テハ合部レシャ此ブ

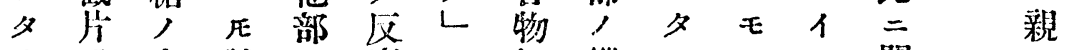

物

营起

雜

?

言志

ざ

第

$\vec{\nabla} \quad-$

觀

It.

祭

七

况

重

卷

襍

受

精

iit.

此

第

百

t

$+$

t

號

》 $\exists$ 存試 $=$ 應 $\ni$ 例縱, ス關

師先在藥比 $\ni$ 用

田

聯

ス

明

ル

治

落

現

修

三

U9

年

前j

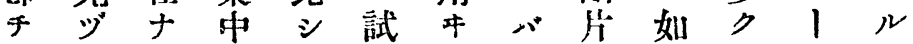




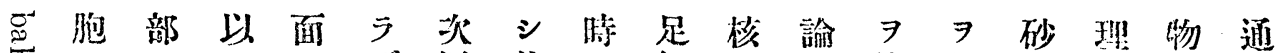
焉

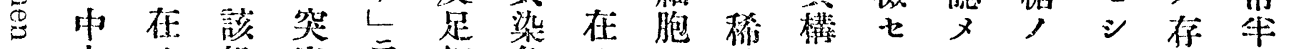

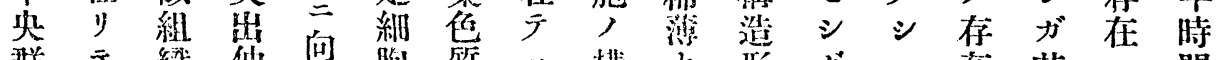

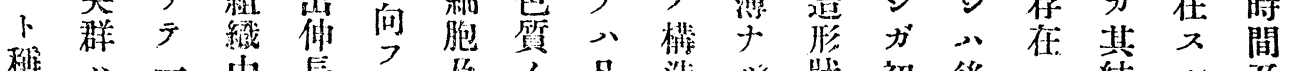

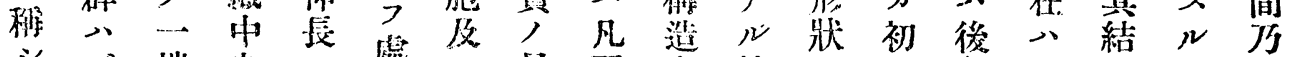

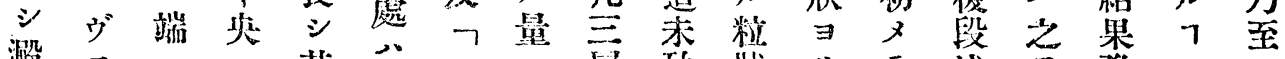
澱 $x$ 心

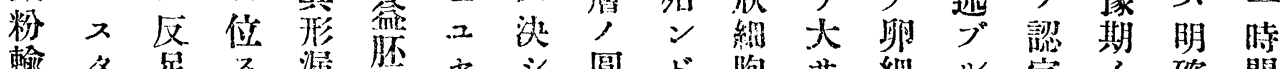

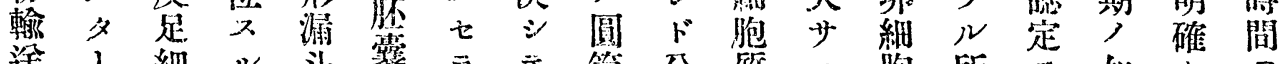

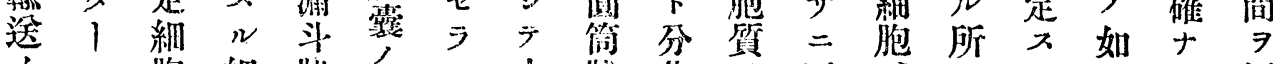
○胞細狀此

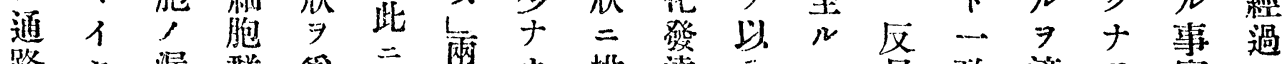

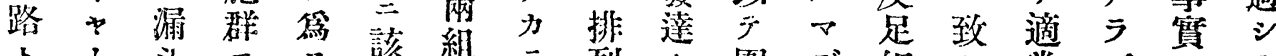

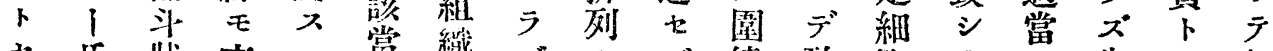
七狀亦二當織 ゙゙セズ繞殆胞テ留失ナ初

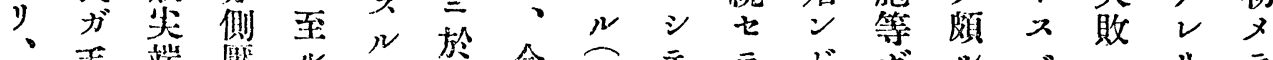

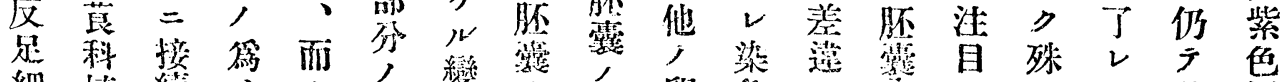

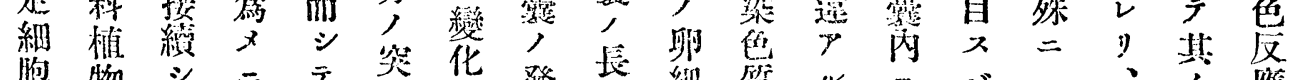

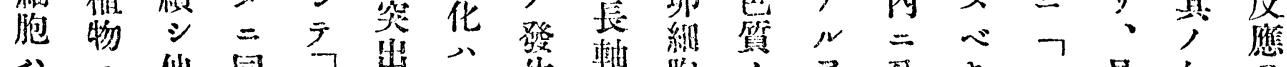

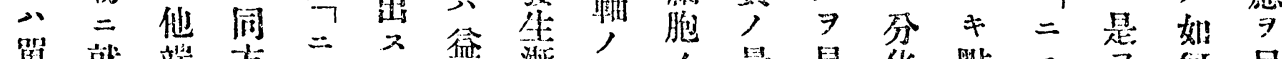

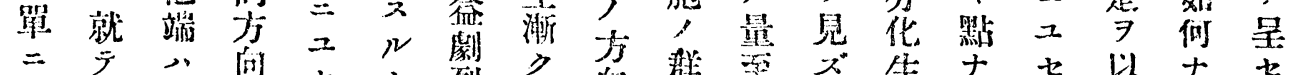

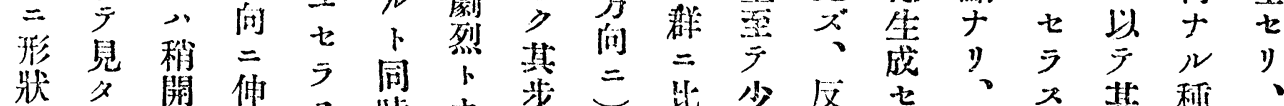

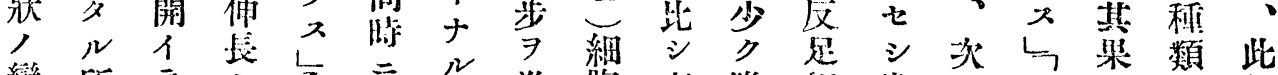

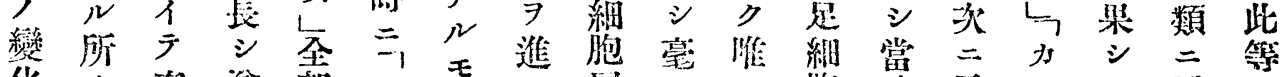

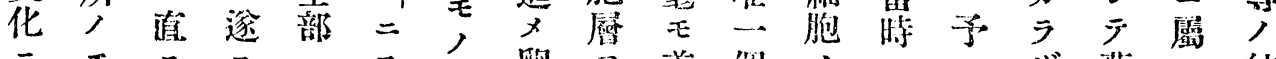

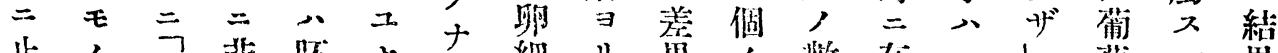

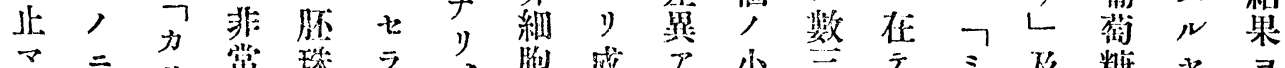

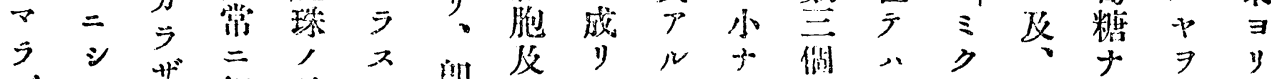

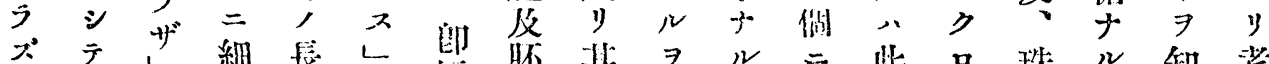
其 E

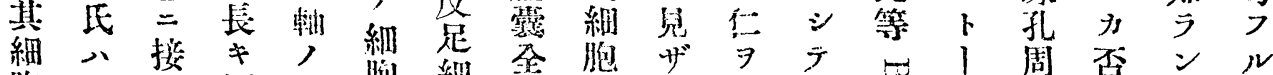
胞 之

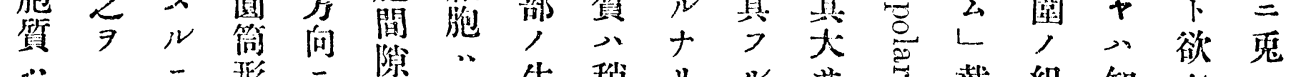

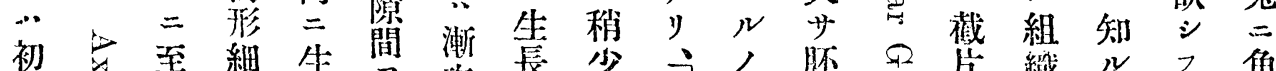

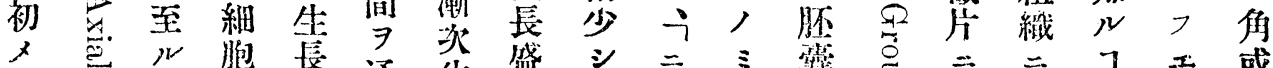

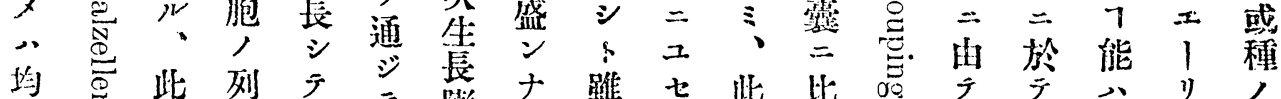

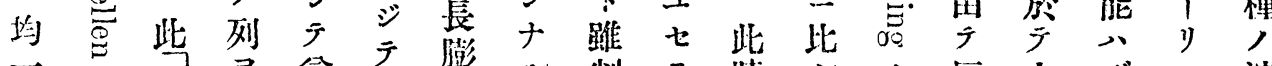
$\overrightarrow{+}$ 或 二

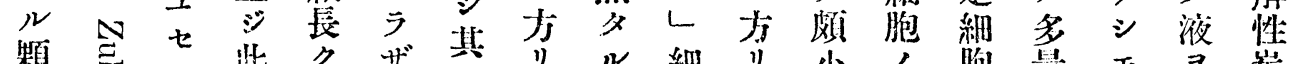

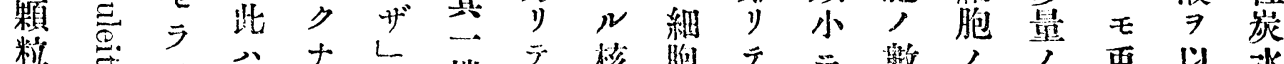

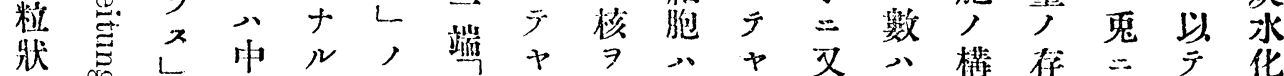
$\Rightarrow$ 尛

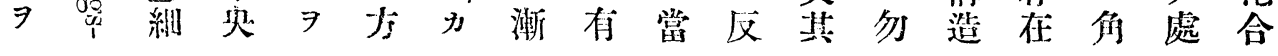




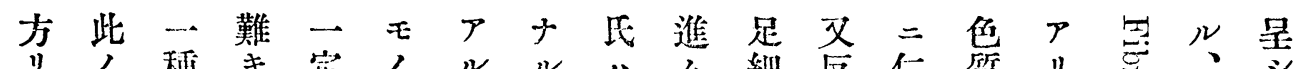

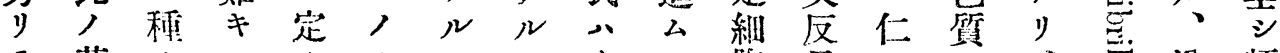

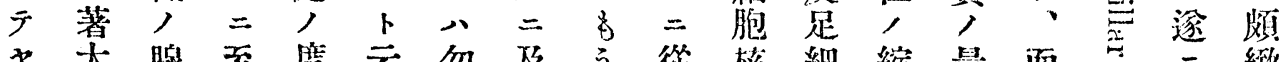

†大腺至度云勿及弓從核細縮最陑心三絰

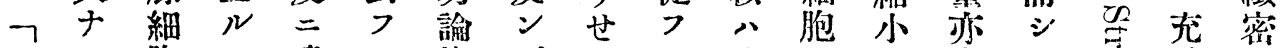

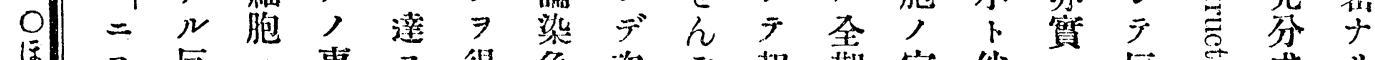

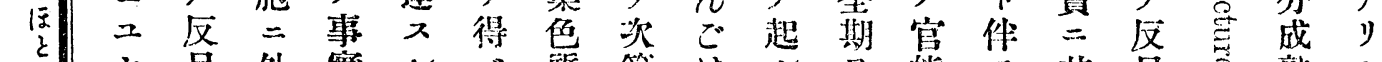

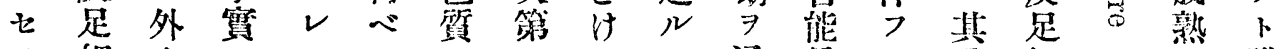

ラ細ナハ八シ八三八通最モ增細八踓

又胞 全茲、化基

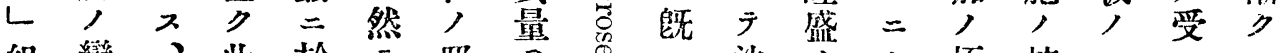

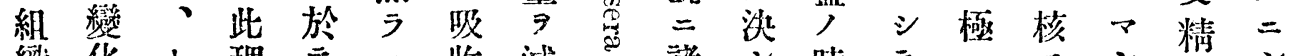

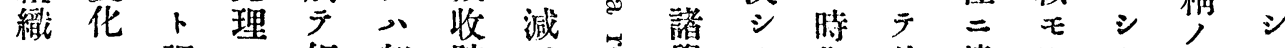

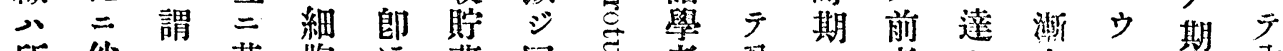

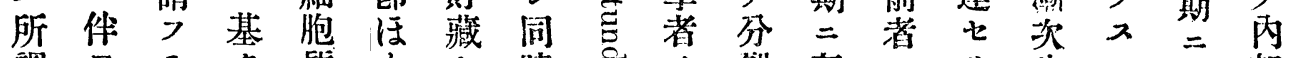

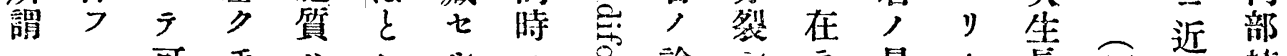

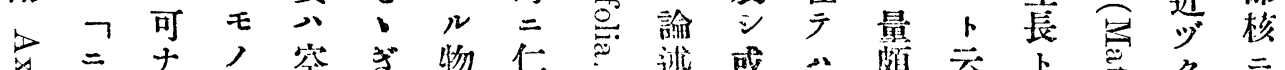

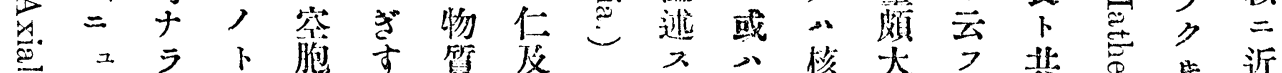

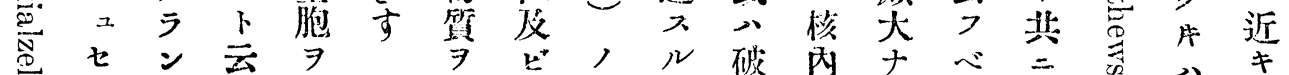
产

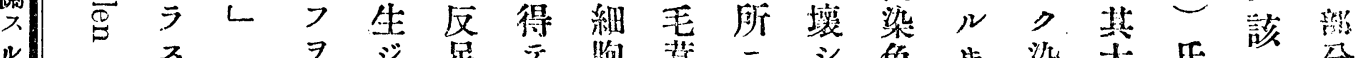

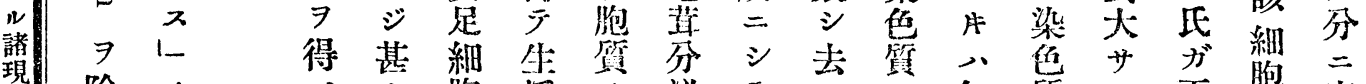
像 除,

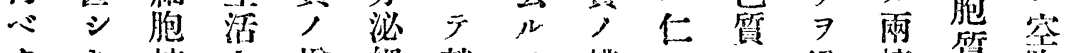

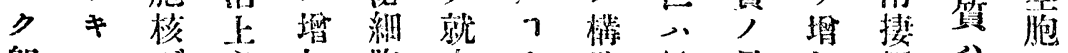

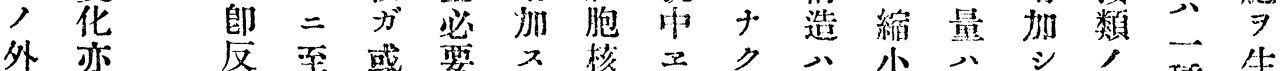

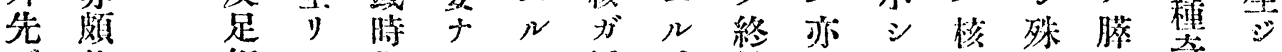

肧 甚

露 $\neq$

,

ᄀᄀ

ラ

ザ、

ᄂ 脴

端 靅

充

接 分

天

$\sim$ 生

部 熟

分

ヨ 受

り 精

破 期

壤

海

始 ”

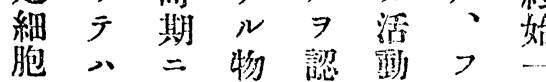

八細於筧

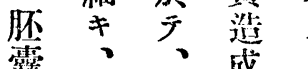

露、成 y

, 赦

營維之作要

養牀二用

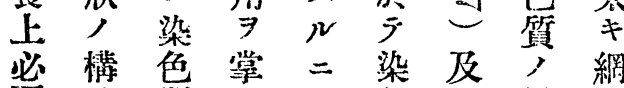

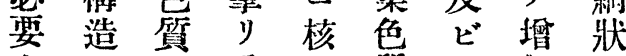

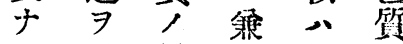

呈量产細

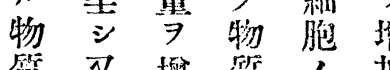

算 刃 倜

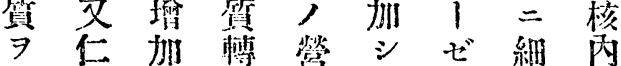

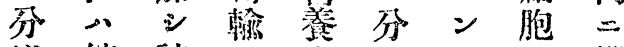

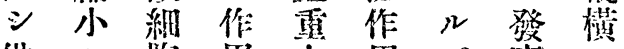

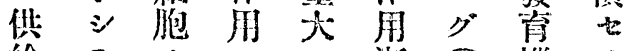

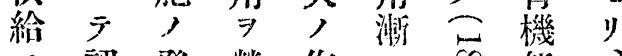

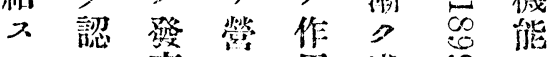

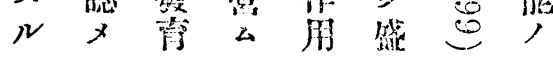

反

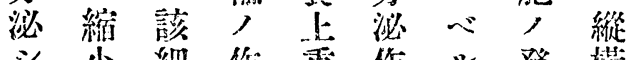

亏; 二 䠞 奇

此

殆容洼分畋空 $x=$ 


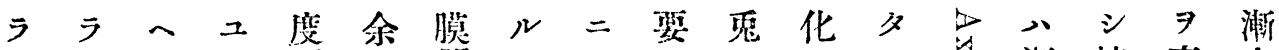

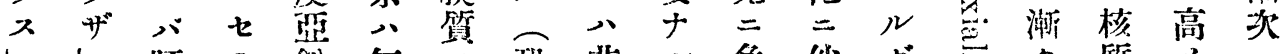

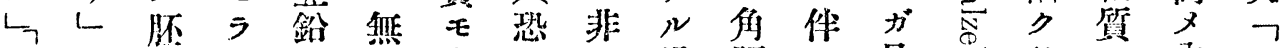

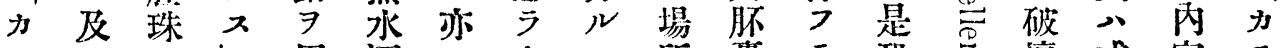

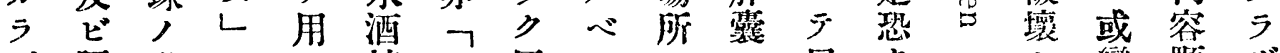

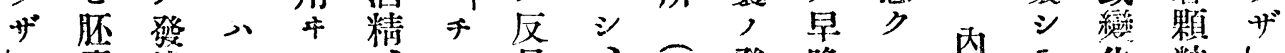

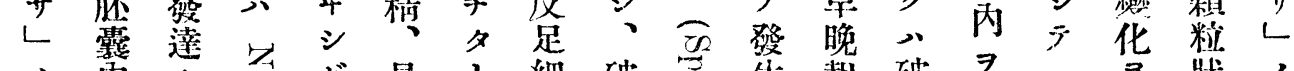
特

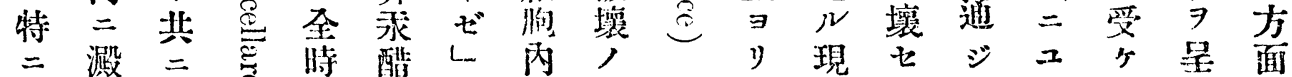

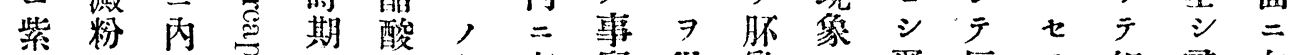

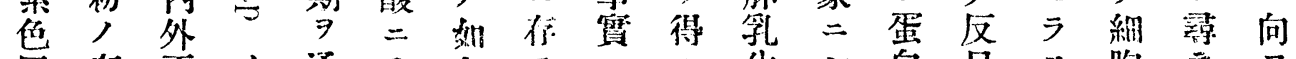

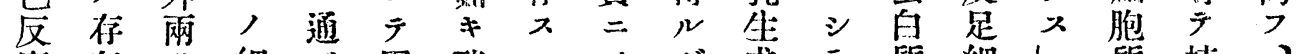

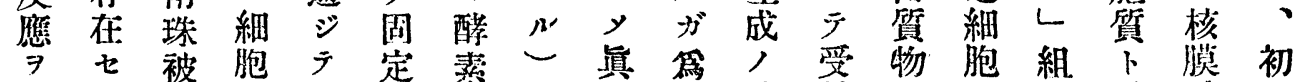

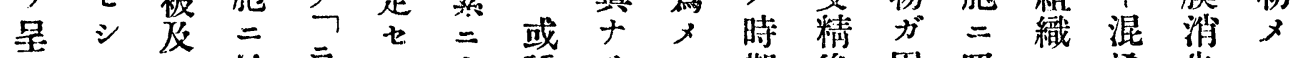

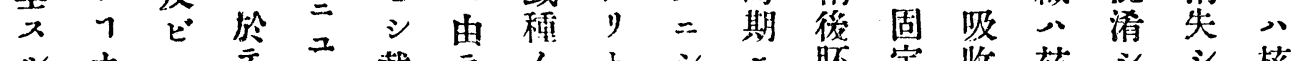

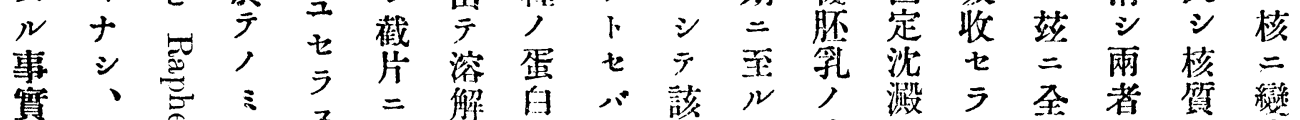

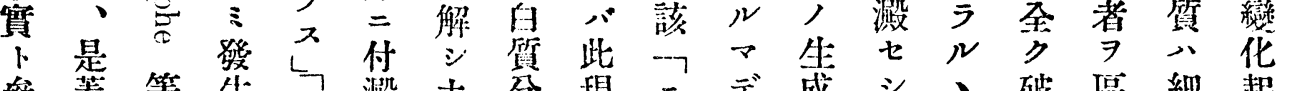

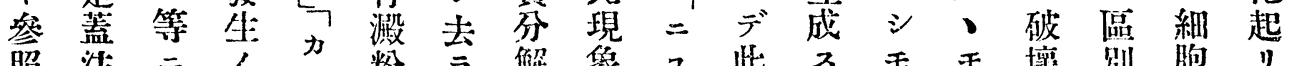

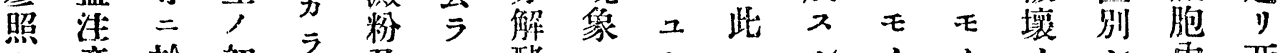

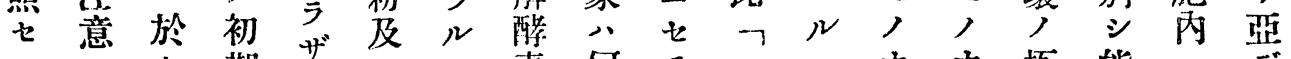

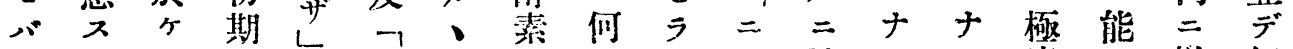

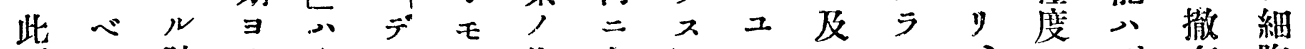

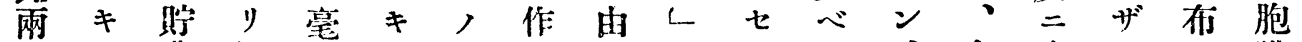
組事藏 媓毛入十角示, 織 實 澱二澱トラ

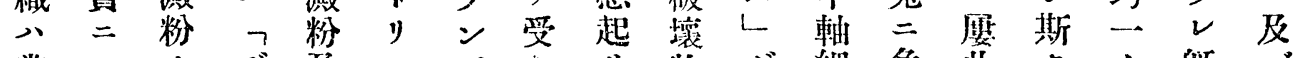

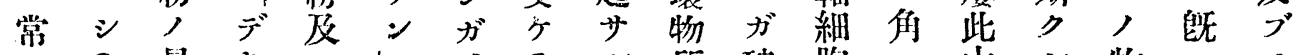
二テ量 $\neq \neg し$ ᄂ

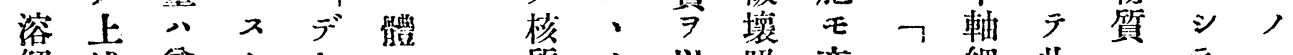
解 述 益卜 性七喤 リ

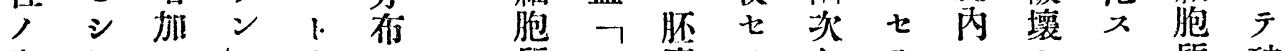

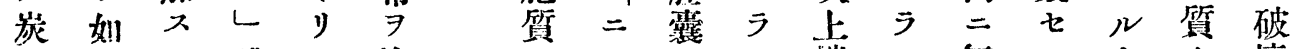

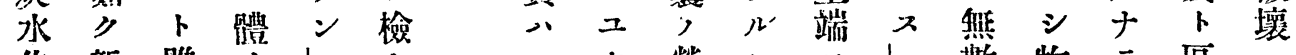
化新雖 $く$ 七

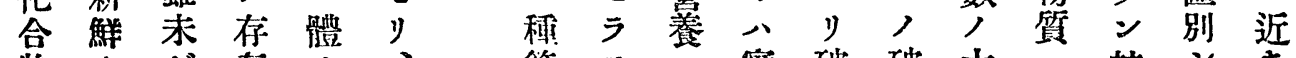

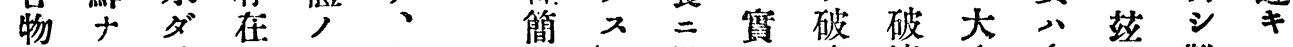
例 曾 $\exists$ 存此易 ᄂ 供 $=$ 壤壞小中二難

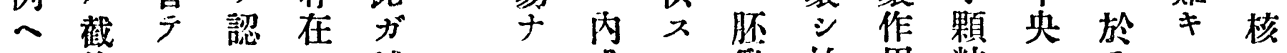
$\therefore$ 片

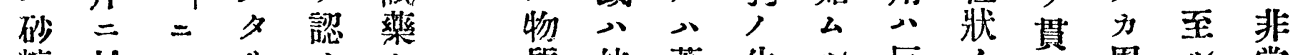
糖於工り 類

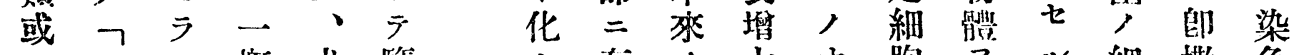

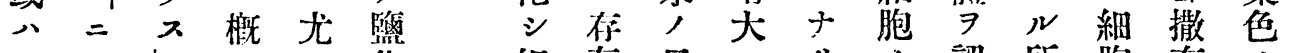

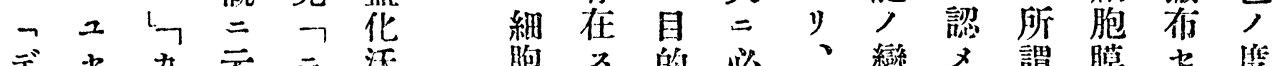
デセカ云二沃

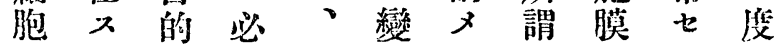




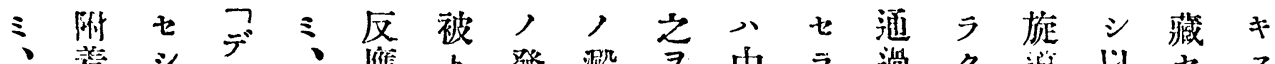

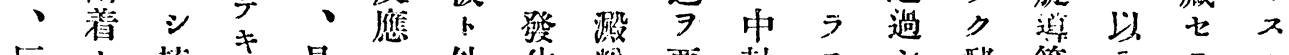
反七核 7 是二外企粉要軸 足ルノ 細細周、 以

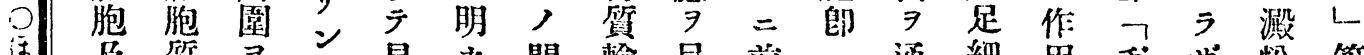

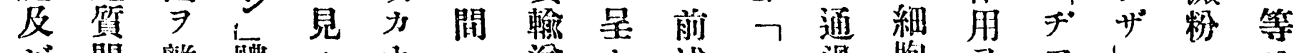

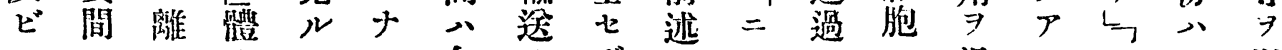
讨

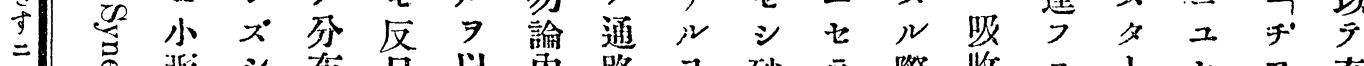

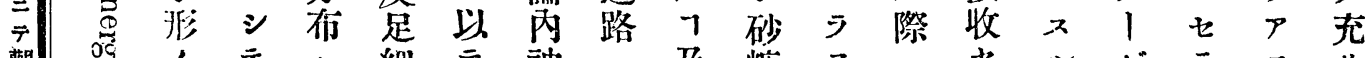
觀器人 テ

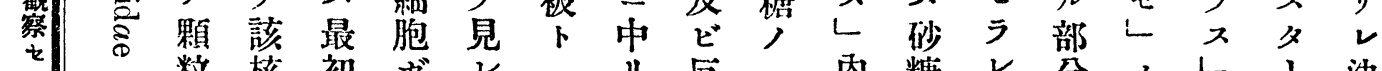

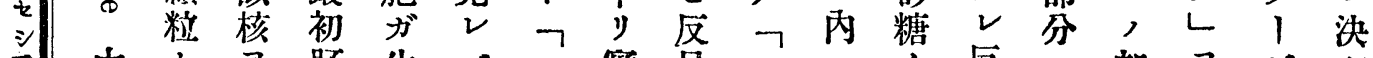
重中下

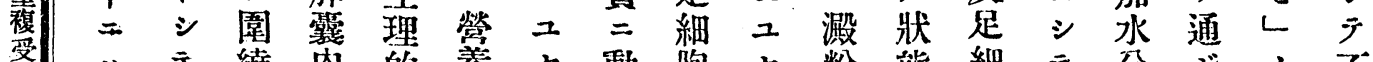

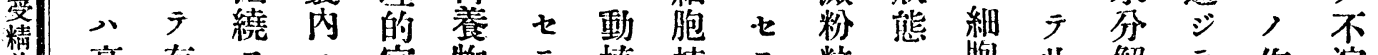
亚 掌存 ス 官物 ラ植核 此

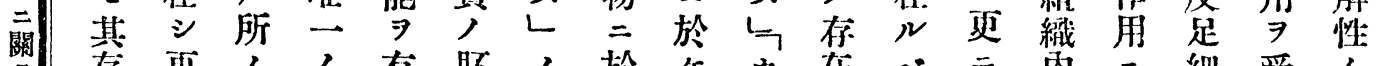

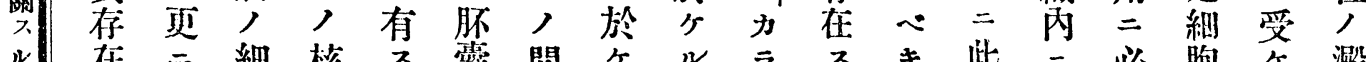

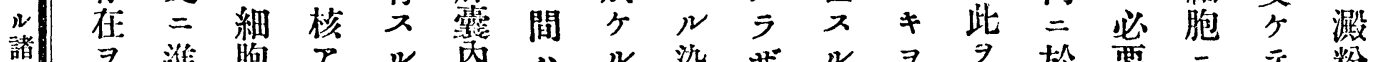

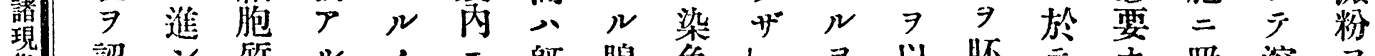

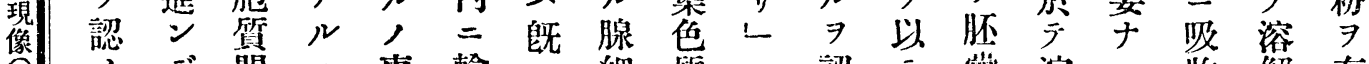
承

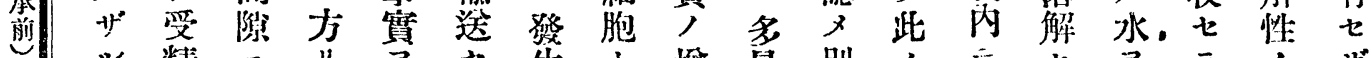
U

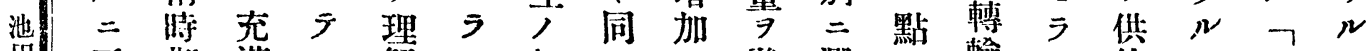
明瑟期满 $\cdots$ 解

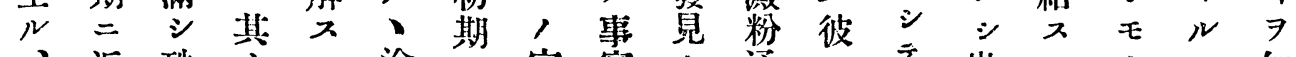

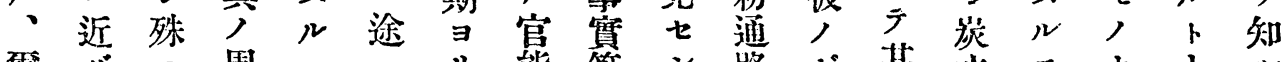

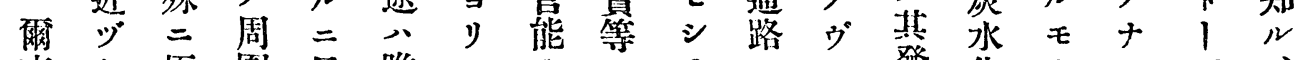

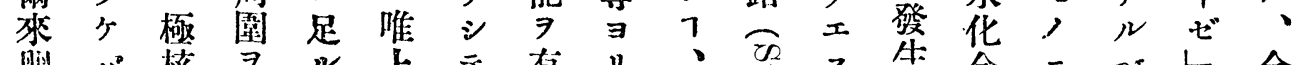
明 細單分国 心゙述 細

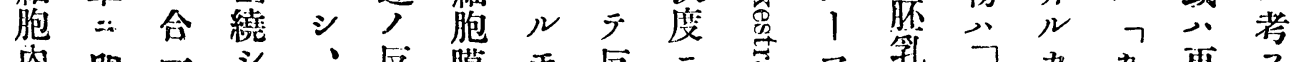
内畉 二細ス爾足

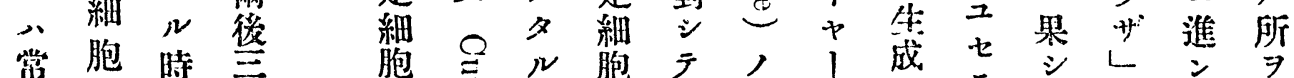

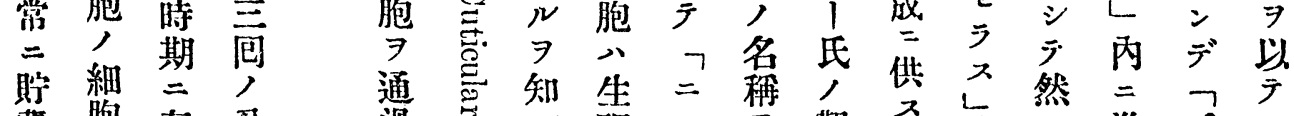

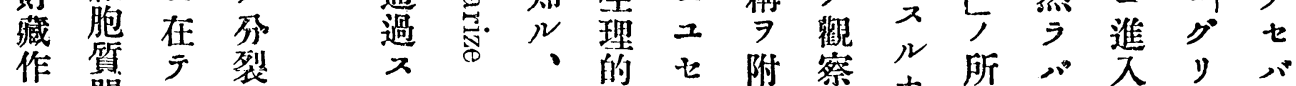
用間 ハ 二

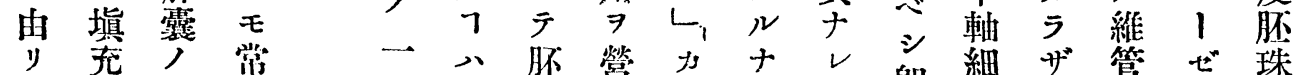

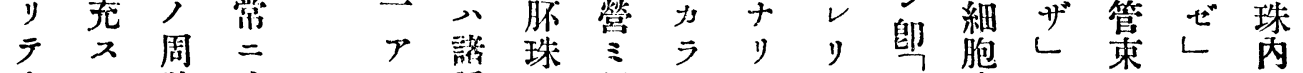
多ル壁生ル程, 脴ザ、、二内ハ人ト二

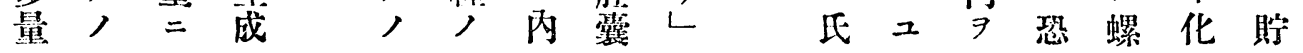




\section{五四 三三}

脴 八脴 二辰 卵 精 螦 二 白孚佔 7 組核旋㑬 成由核, 霝胞心狀了 熟二八極 入八常人, 精 然肧肧核、受三形核

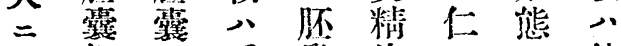
進細厂妥孚後 7 学他

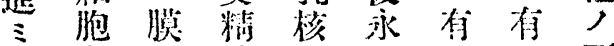
シ 買集前 八

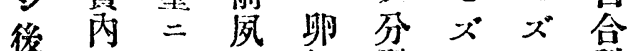
$==$ 近二細裂

$\gamma$ 在 $\neq$ 合胞 $x$

ラリ 部

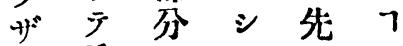

レ驾 二テテナ 心梨來生示》 此 $\exists$ 应速 等 營 亏゙ シ カ デ 胚 分非三残 笔從裂觉 范留 核 辛 莼潮大營 問 二 次形始 食 二怒肧卜メ物

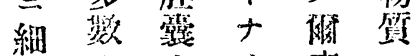
胞, 盟肧内以感丰 了乳 部 テ ン 形核二成二 成 心间熟㔔立

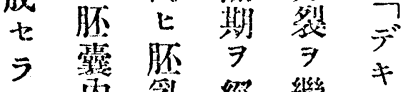
丙乳經繼 到組過就卜

7 烧織 シ シ y

$+=\bar{y} \bar{y}$

シ撒形变肧 之゙

七 期 組

ラ 二䄉

等 達 7 吸

ル不生收

$=7$ 、眝

至ナル藏

N $シ$ =

ノ・等

、噍少充

I 核
テ 科

常 物

$=$ 例

球 -

玨;

教は

ク

त ह

规

斯

少

ル

梳

Hist

$+\quad y$

i)

1 2

啢么

精 等

核 或

大

世科

八椎

非 物

常 二

= 於

差

留 N

$\gamma$ 邚

y $\geqslant$

虫霖

豓

状

或

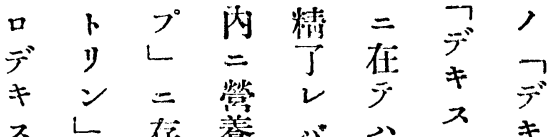

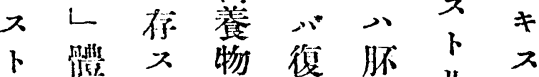

リ $\rightarrow$ 質

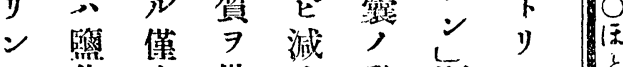

ᄂ 化少供少發顆 ン 第十沃, 絈洪生粒L U度

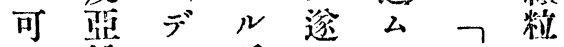
結》鉛 $\neq$ 篇 二小ニ 港 二 粉 数 卜 特 蹟 二セ積 $\exists$ シ $リ=\exists$ 漸 リテン此失》ルル 溶酒しノフ其、モ 解柕顆口、基力, 性色䊉デ是寻

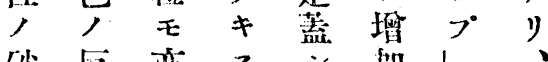

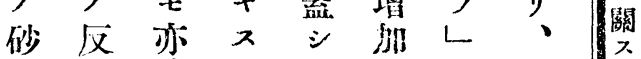
糖鷹溶卜花方及逐 $=\exists$ 解 》粉逐 $\mathrm{E}^{*}=$

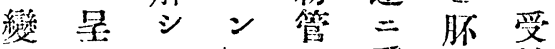
天゙ 天氺受珠精 几 同顆進精内後

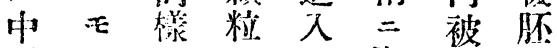
闹,,$>\Rightarrow$ 際,,

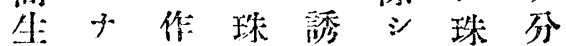
成 2 用孔>化孔裂 物 $\rightarrow$ 二 所粉 $引$ 行 卜第近, 管十 y 工。不不砂; 胃り $、$ 存糖球部、 江, 在液孔分二 心口ナス里 $=二$ 至 キデラル成進, リ

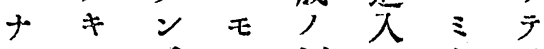
リス、人原 $ス$ 存其 卜凡+料儿在痕 リテ ラ 二際 $\nu$ 上 $ン=N$ 莯十省於正止 落 クルェ進聂ニザ 》所七刀多 所ノラノ量厅た

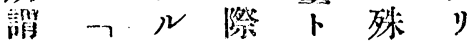
ーデ、花ナ三。 ア キ カ粉》後此 ミスツ管要者他 
卆 八

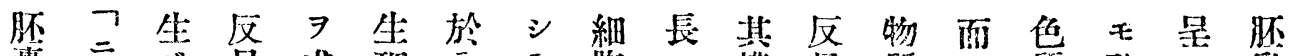

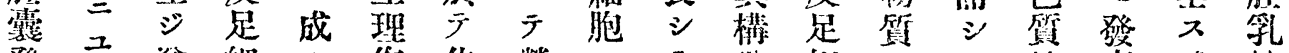

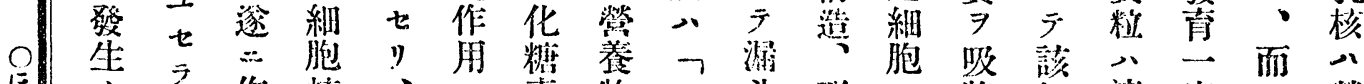

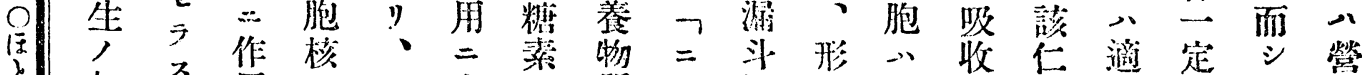

初弪俑核

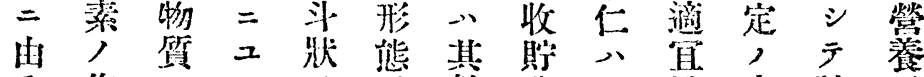

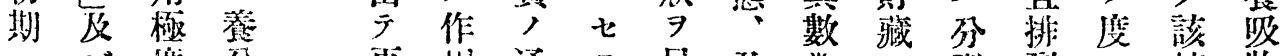

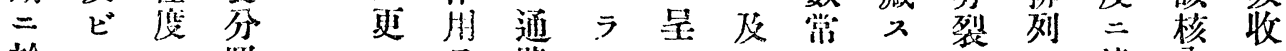
於 ᄀ三紧

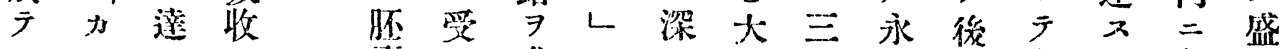

㢣

齐脴 ザ レ 篮

重 筯しバナ

核, 标

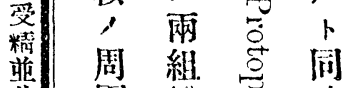

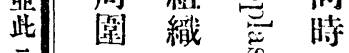

關

胞常要䨔

筑

像 自激的染

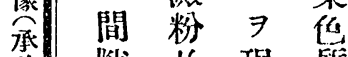

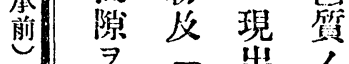

池充 ブス量

夕₹ $\nu$ 皮

七 $x$ 二算

恎加

ᄀ リ $⿻$

デン、仁

$\neq$ ᄂ

入娟却

卜,

y存緶

二在 小

ᄂ $\exists$ 중

體 認少

, $x=$

顆

䊀 - y

$\Rightarrow$

認

4

嘅

$=$

シ

ร
篟分成, 多少假

内于セ中

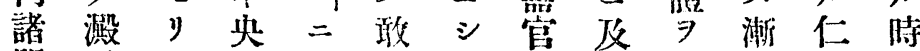

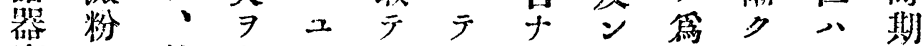

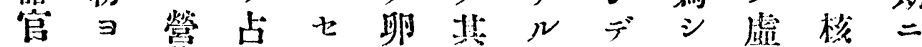

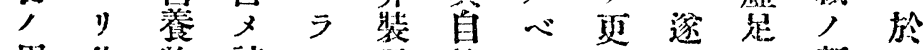

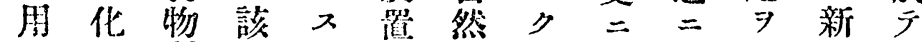
二成留組上, 三其娘分綰煺一

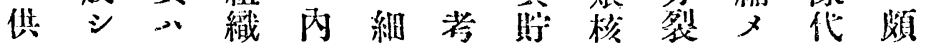
七夕多, 二胞标菩丙期㳄謝裴 ラルク破蕉々

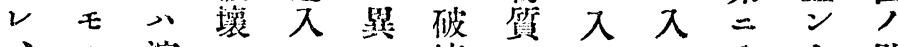
， 溶

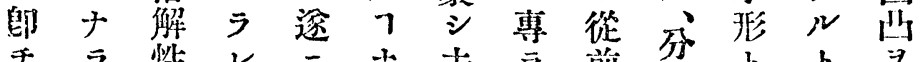

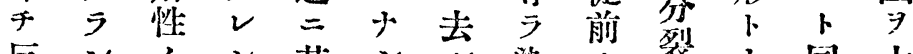

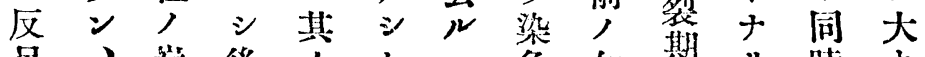

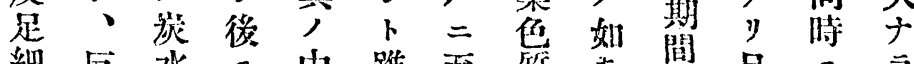

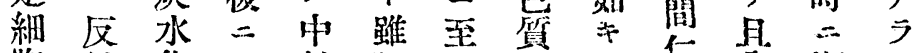

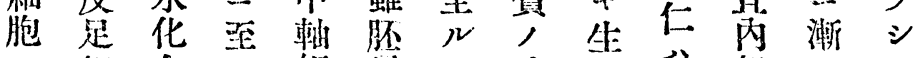

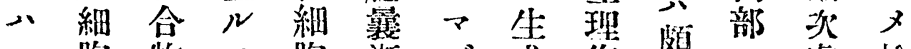
一胞物 $E$ 胞漸 程 $三$ 永群成分二角隻空足毛 , 向王 $\Rightarrow$ 热裂优 $尹$ 华胞的值 腺 $\bar{F} \neg \cdots \bar{z}$ 之管

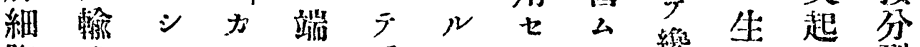

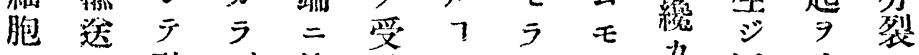
, 七砂ザ速精ナル, 背同生 管亏糖上接期 能 2 類卜久

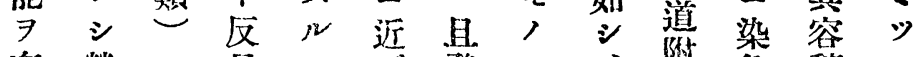
有營二足二永, 、附悉積。

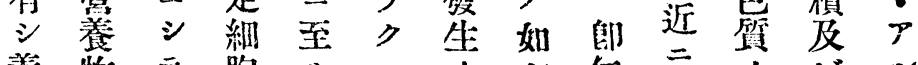

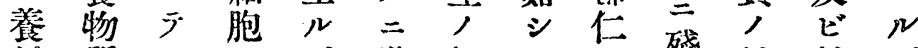

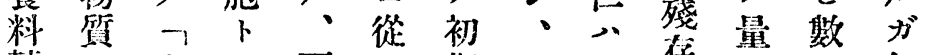
曜

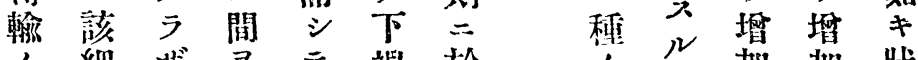

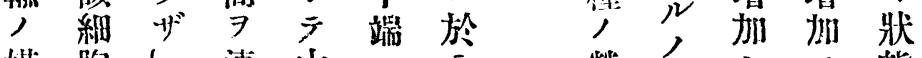
媒胞し連中分營”シ 天態

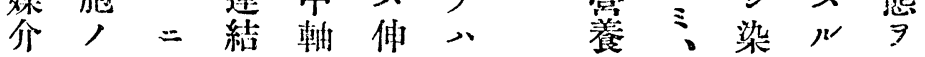




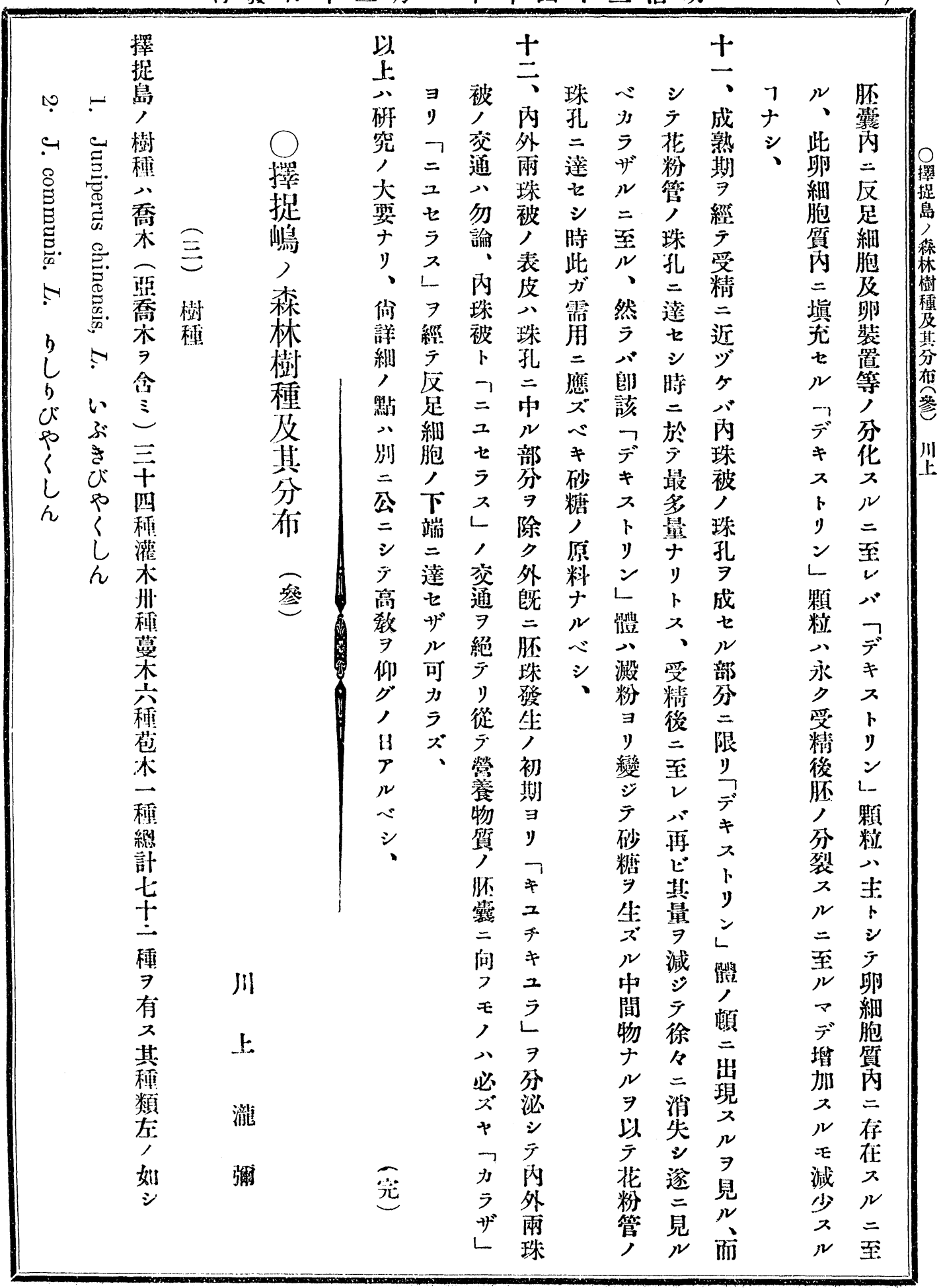

